\title{
BETWEEN ACCULTURATION AND CONVERSION IN ISLAMIC SPAIN \\ THE CASE OF THE BANŪ HASDAY*
}

\author{
SARAH STROUMSA \\ THE HEBREW UNIVERSITY OF JERUSALEM
}

\begin{abstract}
The High Middle Ages in Islamic Spain (al-Andalus) is often described as a golden age in which Jews, Christians and Muslims lived in harmony. The attested dynamics of conversions to Islam disturb this idyllic, static picture, revealing the religious and social pressures exerted on the religious minorities. The different reactions of the Jewish and Christian communities of al-Andalus to these pressures allow us to refine our understanding of conversion in the Medieval Islamic world. A close examination of the Jewish family of Banū Hasday shows more nuances and ambivalence than 'conversion' normally suggests.
\end{abstract}

Key Words

Coversion, acculturation, convivencia, al-Andalus, dhimma, Ibn Șā'id al-Andalusī, Ibn Ḥasday.

Conversion is often used to describe a single dramatic event: a person had one specific identity and through a transformative experience, as if by the waving of a magic wand, this person has been transformed into another: the pagan became a Christian, the Christian became a Muslim, the skeptical philosopher was converted into an orthodox theologian. ${ }^{1}$

* Earlier versions of this paper were read in Berlin, on May 6, 2015, as part of the lecture series: Konversionen: Erzählungen der Umkehr und Bekehrung. Mosse-Lectures and der Humboldt-Universität zu Berlin; and in Ann Arbor, on September 16, 2015, as the Padnos Lecture, at the Jean and Samuel Frankel Center for Jewish Studies, University of Michigan. I wish to thank the conveners of both 
Our main source of knowledge regarding conversion, however, lies in stories: stories presented as personal narratives, stories embedded in archival material and in historiographical, legal, or other types of literature. These stories, even those which intend to convey a very decisive, transformative picture of the conversion-event, reveal a complicated, dynamic conversion process. ${ }^{2}$ The vast and quickly growing scholarly literature devoted to religious conversions highlights, beyond the personal, spiritual or experiential paradigm of conversion, other aspects of this phenomenon: social, economic or legal. ${ }^{3}$ These aspects, the consideration of which renders even the conversion of individuals anything but a one-dimensional events, tend to take priority when we observe the conversion of whole societies.

In what follows I will first broadly describe in general terms the cultural and religious situation that prevailed in the Islamic Middle Ages in the Iberian Peninsula. I will also deal with conversions to Islam in this context, and then present one specific case of conversion from Judaism to Islam.

When the first Muslim conquerors entered the Iberian peninsula, in 92/711, the vast majority of the peninsula's inhabitants were Christians (with perhaps small groups of pagans still lingering in the northern, mountainous areas). ${ }^{4}$ The minuscule Jewish community was on the verge of extinction, due to the Visigoth persecutions and forced conversion; and obviously, at this point the Muslim

events, as well as the participants therein, for their helpful comments. I also thank the anonymous reviewers for Mediterranea for their helpful comments on the draft of this article.

1 See, for example, Jason David BeDuhn, Augustine's Manichaean Dilemma. 1. Conversion and Apostasy, 373-388 C. E., Philadelphia: University of Pennsylvania Press, 2010, p. 193, where conversion is presented as 'a sudden, dramatic, and complete transformation of the self, instantly creating a new person changed to the core'. On the prevalence of the understanding of conversion as primarily this dramatic, personal transformation, despite many studies that present different or more nuanced understandings, see Arietta Papaconstantinou, 'Introduction', in A. Papaconstantinou, Neil McLynn and Daniel Schwartz (eds.), Conversion in Late Antique Christianity, Islam, and beyond. Papers from the Andrew W. Mellon Foundation Sawyer Seminar. University of Oxford 2009-2010, Farnham: Ashgate, 2015, pp. xv-xxxvii.

2 See Ryan Szpiech, Conversion and Narrative: Reading and Religious Authority in Medieval Polemics, Philadelphia: University of Pennsylvania Press, 2013). On the merit of such anecdotal, nonquantifiable data, see apud n. 31.

3 For an overview of this literature, see, for instance, Szpiech, Conversion and Narrative, pp. 14-17; Papaconstantinou, 'Introduction', pp. xv-xxxvii, especially note 5.

4 See David J. Wasserstein, The Rise and Fall of the Party-Kings: Politics and Society in Islamic Spain 10021086, Princeton: Princeton University Press, 1985, p. 225; C.-E. Dufourcq, 'Le christianisme dans les pays de l'Occident musulman des alentours de l'an mil jusqu'aux temps almohades', Études de civilisation médiévale (IXe-XII siècles). Mélanges offerts à Edmond-René Labande à l'occasion de son départ à la retraite et du XXe anniversaire du C.E.S.C.M. par ses amis, ses collégues, ses élèves, Poitiers: Centre d'études supérieures de civilisation mediévale, 1974, pp. 237-246, at p. 237. 
Between Acculturation and Conversion on Islamic Spain

conquerors themselves made up only a very small part of the population, as conquering armies do. We do not know exactly how the process of conversion to Islam advanced from this point of departure. We may assume that, in many ways, the conversion process in al-Andalus followed similar patterns to the conversion to Islam across the Muslim world, where the small community of Muslims lived at first in garrisons, separated from the rest of the population, on which they did not impose the adoption of Islam. The process of conversion was probably not steady and linear, and in many cases we can see a pattern of uncertain, unstable conversions, where individuals and even small communities converted, then repented and returned to their original religion. ${ }^{5}$ But with the passing of time, the religious profile of the conquered areas changed, and the indigenous population gradually became predominantly Muslim. Genuine religious change of heart and true conviction in the veracity of the new religion must of course be taken into account as the primary drive for many conversions to Islam. But other considerations seem to have played at least as important a role: fiscal and agricultural policies which imposed higher taxes on non-Muslims; social practices which, together with conversion, attached the convert to an Arab tribe and family, promising to facilitate networking and perhaps the entrance to the ruling classes; and occasional discriminatory laws and practices which (gently or not so gently, depending on the specific regime) put pressure on the local populations to convert to Islam. ${ }^{6}$

See Uriel Simonsohn, 'Conversion, Apostasy and Penance: The Shifting Identities of Muslim Converts In the Early Islamic Period', in Papaconstantinou et al., Conversion, pp. 197-218, especially, p. 196.

6 On the various reasons for conversion to Islam, see Richard W. Bulliet, 'Process and Status in Conversion and Continuity', Introduction to Michael Gervers and Ramzi Jibran Bikhazi (eds.), Conversion and Continuity: Indigenous Christian Communities in Islamic Lands, Eighth to Eighteenth Centuries, Toronto: Pontifical Institute of Mediaeval Studies, 1990, pp. 1--12, at pp. 4--8; David J. Wasserstein, 'Conversion and the Ahl al-Dhimma', in Robert Irwin (ed.), The New Cambridge History of Islam, Volume 4: Islamic Cultures and Societies to the End of the Eighteenth Century, Cambridge: Cambridge University Press, 2010, pp. 184-208, at pp. 185-87; Arietta Papaconstantinou, 'Between Umma and Dhimma: The Christians of the Middle East under the Umayyads', Annales Islamologiques 42 (2008, pp. 127-156, at p. 151; Mercedes García-Arenal, 'Rapports entre les groupes dans la péninsule Ibérique: La conversion de juifs à l'islam (XII XIII ${ }^{\mathrm{e}}$ siècles)', Minorités religieuses dans l'Espagne médiévale. Revue du Monde Musulman et de la Méditerranée 63-4 (1992, pp. 91-102, at p. 92). See also Yohanan Friedmann, Tolerance and Coercion in Islam: Interfaith Relations in the Muslim Tradition, Cambridge: Cambridge University Press, 2003, pp. 87-120. The mixture of spiritual and practical reasons for converting is of course not unique to conversion to Islam; a similar admixture can be seen, for example, in the conversion of Muslims to Christianity in the Iberian peninsula; see Benjamin Z. Kedar, Crusade and Mission: European Approaches toward the Muslims, Princeton: Princeton University Press, 1984, pp. 43-44. 
Be that as it may, in the Iberian peninsula as in the rest of the Islamic world, a relatively short time after the dust of the conquests settles (that is to say, one or two centuries later), we find that the conquered area which came to be known as al-Andalus has become Muslim: under firm Muslim rule, with Islam as the dominant religion, and perhaps even more importantly, with Arabic as the predominant administrative and cultural language. ${ }^{7}$ Statistics regarding this period are very conjectural, and we cannot say with any amount of certainty at what point the majority of the population did become Muslim. ${ }^{8}$ But it seems safe to say that, by the tenth century, the Muslims of al-Andalus felt and behaved as an undisputed ruling majority.

The High Middle Ages in al-Andalus are often described as a golden age of inter-religious convivencia or harmonious symbiosis between the different communities, where Judaism, Christianity and Islam - las tres culturas - lived harmoniously under the aegis of Islam. Much has been written to explain the development of the terms used in this description and to correct the historical validity of their rosy interpretation, and we need not go into it here. ${ }^{9}$ Suffice it to

This, as well as the observations regarding language in the following pages, is of course a crude, static and simplified summary of a very complex and shifting linguistic situation. For a summary of (some of) the complexities, see Robert I. Burns, Muslims, Christians, and Jews in the crusader kingdom of Valencia: Societies in symbiosis, Cambridge: Cambridge University Press, 1984, pp. 172-179; and see further below, n. 24.

8 See Richard W. Bulliet, Conversion to Islam in the Medieval Period: An Essay in Quantitative History, Cambridge, Mass.: Harvard University Press, 1979, especially, pp. 114-127; Jean M. Fiey, 'Conversions à l'Islam de juifs et de chrétiens sous les abbassides d'après les sources arabes et syriaques', in Johannes Irmscher (ed.), Rapports entre juifs, chrétiens et musulmans: Eine Sammlung von Forschungsbeiträgen, Amsterdam: A.M. Hakkert, 1995, pp. 13-28, at p. 13 and n. 2; Michael Morony, 'The Age of Conversions', in Gervers and Bikhazi, Conversion and Continuity, pp. 135-50; Wasserstein, 'Conversion and the Ahl al-Dhimma', pp. 184-85. On the conversion process in alAndalus, see A. G. Chejne, 'Islamization and Arabisation in al-Andalus: A general View', in Speros Vryonis (ed.), Islam and Cultural Changes in the Middle Ages, Wiesbaden: Harassowitz, 1975, pp. 59-86; Thomas F. Glick, Islamic and Christian Spain in the Early Middle Ages, Princeton: Princeton University Press, 1979, pp. 33-35, 282-283; Thomas F. Glick, From Muslim fortress to Christian castle: Social and cultural change in medieval Spain, Manchester-New York: Manchester University Press, 1995, pp. 51-60; Mayte Penelas, 'Some remarks on Coversion to Islam in alAndalus', al-Qantara 23/1 (2002), pp. 193-200; Cyrille Aillet, 'Islamisation et arabisation dans le monde musulman médiéval: une introduction au cas de l'Occident musulman (VII $-\mathrm{XII}^{\mathrm{e}}$ siècle)', in Dominique Valérian (ed.), Islamisation et arabisation de l'Occident musulman médiéval (VII ${ }^{e}$ XII ${ }^{e}$ siècle), Paris: Publications de la Sorbonne, 2011, pp. 7-34; Ragnhild Johnsrud Zorgati, Pluralism in the Middle Ages: Hybrid Identities, Conversion and Mixed Marriages in Medieval Iberia, New York: Routledge, 2012, pp. 25-31; Alwyn Harrison, 'Behind the curve: Bulliet and conversion to Islam in al-Andalus revisited', Al-Masāq 24/1 (2012), pp. 35-51; David Wasserstein, 'Where have all the converts gone? Difficulties in the study of conversion in al-Andalus', Al-Qanțara 33 (2012), pp. $325-42$.

9 As examples for the many discussions of this topic, see Wasserstein, The Rise and Fall of the PartyKings, p. 225; Manuela Marín and Joseph Pérez, 'L'Espagne des trois religions' du mythe aux 
Between Acculturation and Conversion on Islamic Spain

say that, to the extent that this description reflects some reality, as it does, Islamic Spain is only one of many examples of the inter-cultural effervescence under medieval Islam, across the Islamic world. And yet, while Islamic Iberia was as a rule more tolerant to its minorities than medieval Christian Europe, or even more precisely: than medieval Christian Spain, its presentation as a model of tolerance is highly anachronistic: in 459/1066 Islamic Granada was the scene of one of the rare anti-Jewish pogroms under medieval Islam, and the first expulsion from Spain, affecting both Jews and Christians, happened already in the twelfth century, under Islam. ${ }^{10}$

The attested gradual conversion of most of the conquered Christian population to Islam casts a shadow over the 'golden age' idyllic, static picture. The conversions reflect the religious and social pressures exerted on the subordinated Christians, pressures without which many if not most of them would probably not have converted.

Theoretically, the same pressures were brought to bear on Jews and Christians alike, and thus should have affected Jews and Christians equally. But in alAndalus as elsewhere in Islamic territory, notwithstanding a continuous phenomenon of individual Jewish conversions to Islam, the Jewish communities survived for centuries, whereas the Christian communities progressively shrank,

réalités: Introduction', in Manuela Marín and Joseph Pérez (eds.), Minorités religieuses dans l'Espagne médiévale (Revue du Monde Musulman et de la Méditerranée 63) (1993), pp. 23-27; Serafín Fanjul, La Quimera de al-Andalus, Madrid: Siglo XXI, 2004, especially pp. 21-53 ('el mito de las tres culturas'); M. García-Arenal, 'Rapports entre les groupes', p. 91; Alex Novikoff, 'Between Tolerance and Intolerance in Medieval Spain: An Historiographic Enigma', Medieval Encounters 11 (2005), pp. 7-36; Kenneth Baxter Wolf, 'Convivencia in Medieval Spain: A Brief History of an Idea', Religion Compass 3/1 (2009), pp. 72-85; Anna Akasoy, 'Convivencia and its Discontents', International Journal of Middle East Studies 42 (2010), pp. 489-499, especially pp. 489-490, 495-497; Ryan Szpiech, 'The Convivencia Wars: Decoding Historiography's Polemic with Philology', in Susan Akbari and Karla Mallette (eds.), A Sea of Languages: Rethinking the Arabic Role in Medieval Literary History, Toronto: University of Toronto Press, 2013, pp. 135-161, especially pp. 135-141; Nikolas Jaspert, 'Mendicants, Jews and Muslims at Court in the Crown of Aragon: Social Practices and Inter-Religious Communication', in Marc von der Höh, Nikolas Jaspert and Jenny Rahel Osterie (eds.), Cultural Brokers at Mediterranean Courts in the Middle Ages, Paderborn: Ferdinand Schöningh, 2013, pp. 107-147, at p. 125; Alejandro García Sanjuán 'La distorsión de alAndalus en la memoria histórica española', Intus-legere Historia 7 (2013, pp. 61-76).

10 There are several possible explanations for Spain's special place in modern historiography, prominent among them the fact that Spain is a European country. When Spain is associated with the non-European world, the European prejudice can have the opposite effect. Sylvain Gouguenheim, for example, who attempts to prove a direct link from Athens to Christian Europe, hardly mentions Spain in his discussion of medieval philosophy; see his Aristote au Mont-Saint-Michel: Les racines grecques de l'Europe chrétienne, Paris: Le Seuil, 2008); and see JeanChristophe Attias, 'Judaïsme: le tiers exclu de l'Europe chrétienne', in Philippe Büttgen, Alain de Libera, Marwan Rashed, and Irène Rosier-Catach (eds.), Les Grecs, les Arabes et nous: Enquête sur l'islamophobie savante, Paris: Fayard, 2009, pp. 213-222, at p. 213. 
in some areas up to their total disappearance. This difference is forcefully presented by David Wasserstein, who says that, if one considers what he calls 'the indeterminate amorphous mass of the community as a whole', one can observe that it is this group that, taken in its totality, converted to Islam among the Christians and it is this group, among the Jews, that seems not to have converted'. ${ }^{11}$

One conspicuous example of this difference, in the vicinity of al-Andalus and under a political rule that also controlled al-Andalus, will suffice. In the twelfth century the Berber dynasty of the Almohads took hold of North Africa and alAndalus. The Almohads' peculiar religious interpretation of Sunni Islam is notorious for its deviation regarding the place granted to the religious minorities. As is well known, orthodox Islam - both Sunnite and shi'ite normally recognizes the Jews and the Christians as 'people of the book', that is to say, monotheists following revealed religions, and as such allowed to enjoy a state of protection (dhimma) as subordinated, tolerated religious communities. The Almohads, on the other hand, abolished the state of protection and compelled the local Jews and Christians to convert to Islam or go into exile. ${ }^{12}$ Many of the Jews and Christians living under Almohad rule converted to Islam

11 David J. Wasserstein, 'Islamisation and the Conversion of the Jews', in Mercedes García-Arenal (ed.), Conversions islamiques: identités religieuses en islam méditerranéen (=Islamic Conversions: Religious Identities in Mediterranean Islam), Paris: Maisonneuve et Larose, 2001, pp. 49-60, at p. 54. Fiey ('Conversions à l'Islam', pp. 13-14), who speaks of 'massive conversion to Islam by Jews and Christians' alike, seems to rely mostly on anecdotal testimonies regarding those who did convert (and incidentally, includes in his examples of Jewish converts to Islam also a Christian convert, 'Alī b. Rabbān al-Ṭabarī; see Fiey, 'Conversions à l'Islam', p. 19 and p. 24).

12 The Almohad policy towards the religious minorities received much scholarly attention, presenting different evaluations of its motivations, intensity, development and effects; see, for example, David Corcos, 'The Attitude of the Almohads towards the Jews', Studies in the History of the Jews of Morocco, Jerusalem: R. Mass, 1976, pp. 319-342 [in Hebrew]; translated by Elisheva Machlis, and with additional bibliographical notes, in David Corcos, 'The nature of the Almohad rulers' treatment of the Jews', Journal of Medieval Iberian Studies 2/2 [2010], pp. 5-48); S. Stroumsa, Maimonides in his World: Portrait of a Mediterranean Thinker, Princeton: Princeton University Press, 2009, pp. 56-58; Amira K. Bennison and María Ángeles Gallego, 'Religious minorities under the Almohads: an introduction', Journal of Medieval Iberian Studies 2/2 (2010), pp. 143-154; Maribel Fierro, 'Conversion, ancestry and universal religions: the case of the Almohads in the Islamic West (sixth/twelfth-seventh/thirteenth centuries)', Journal of Medieval Iberian Studies 2/2 (2010), pp. 155-173; Maribel Fierro, 'A Muslim land without Jews or Christians: Almohad policies regarding the "protected people", in Matthias M. Tischler and Alexander Fidora (eds.), Christlicher Norden - Muslimischer Süden. Ansprüche und Wirklichkeiten von Christen, Juden und Muslimen auf der Iberischen Halbinsel im Hoch- und Spätmittelalter, Münster: Aschendorff Verlag, 2011, pp. 231-247; Mohamed Chérif, 'Encore sur le statut de dimmis sous les Almohades', in Maribel Fierro and John Tolan (eds.), The Legal Status of Dimmī-s in the Islamic West (second/eightninth/fifteenth centuries, Turnhout: Brepols, 2013, pp. 65-87. The scholarly positions regarding this question merit further discussion, which I intend to offer elsewhere. 
under these conditions, but the long-term effects on the two communities were drastically different. For the Christian communities of North Africa this forced conversion meant a death warrant, and they were effectively wiped out. The Jewish communities, on the other hand, by and large survived the persecution. Jews managed to preserve their religious identity while simulating conversion, and even before the formal abolition of Almohad rule in 1230, the Jewish communities of North Africa surfaced again. ${ }^{13}$

The difference in this respect between these two groups becomes even clearer in the Iberian peninsula itself. Apart from their shared status as 'subordinated religions', the Jews and Christians of al-Andalus present two drastically different communities in their social fabric and consequently also in their religious behavior. The Jewish community was mostly made up of immigrants or their descendants. These immigrants came from the Orient or from North Africa and settled in al-Andalus, usually in the cities, after the Muslim conquest. ${ }^{14}$ The number of Jews who made up these urban Jewish communities could not have been very high, but they seem to have been well integrated economically and culturally. ${ }^{15}$ The Christians, by contrast, constituted at the beginning of this period, as mentioned above, the vast majority of the population, and the

13 See H. Z Hirschberg, A History of the Jews in North Africa, Leiden: Brill, 1974, vol. I, pp. 193-96, and pp. 201-202; M. Talbi, 'Le christianisme magrébin de la conquête musulmane à sa disparition: une tentative d'explication', in Gervers and Bikhazi, Conversion and Continuity, pp. 313-351; Henri Teissier, 'La desaparición de la antigua iglesia de África', in H. Teissier and R. Lourido Diaz (eds.), El Cristianismo en el norte de África, Madrid: MAPFRE, 1993, pp. 37-54, especially p. 44; Thomas E. Burman, Religious Polemic and the Intellectual History of the Mozarabs, c.1050-1200, Leiden-New York: Brill, 1994, p. 191; J.-P. Molénat, 'Sur le rôle des Almohades dans la fin du christianisme local au Maghreb et en al-Andalus', Al-Qanțara 18 (1997), pp. 389-413 See also García-Arenal, 'Rapports entre les groupes', pp. 95-97; Stroumsa, Maimonides in his World, pp. 56-58; and see below, n. 27.

14 The urban character of the Jewish population was not uniform over time, and at least after the $13^{\text {th }}$ century, and under Christian rule, Jews (who were still principally city dwellers) nevertheless owned land; see Jonathan Ray, The Sephardic Frontier: The Reconquista and the Jewish Community in Medieval Iberia, Ithaca-London: Cornell University Press, 2006, pp. 36-42.

15 This situation is summarized by Wasserstein ('Islamisation and the Conversion of the Jews', $p$. 55) who states that 'Islam did... arrive and saved the Jews.' Wasserstein ('Islamisation and the Conversion of the Jews', pp. 55-56) argues that ' $[\mathrm{t}] \mathrm{he}$ conquests brought virtually all the Jews of the seventh-century into a single political system and made them part of a single cultural unit. They made possible contact between different parts of the Jewish world from Iran to Andalus, contact which would have been unimaginable before the rise of Islam'. On the size of the Jewish community in al-Andalus, see also S. D. Goitein, 'Jewish Society and Institutions under Islam', in H.H. Ben-Sasson and S. Ettinger (eds.), Jewish Society Through the Ages, New York: Schocken, 1969, pp. 170-184, at p.173. Goitein estimates that Jews 'did not amount to more than one percent of the total population - with the important qualification that in the cities and towns... they formed a far higher percentage of the inhabitants'. Regarding the various Jewish communities in the cities of al-Andalus, see already Henri Pérès, La poésie andalouse en arabe classique au XI siècle: Ses aspects généraux et sa valeur documentaire, Paris: Adrien-Maisonneuve, 1937, pp. 264-268. 
character of the community did not change drastically when their numbers began to shrink: they were mostly indigenous; and most of them lived in rural communities. ${ }^{16}$

One could have expected the big, ancient and well-established local Christian community to be more resilient to the pressure to convert to Islam than the small, newly established Jewish community. Furthermore, one would have expected the presence of the bordering Christian kingdoms in the North of the peninsula to serve as a source of religious strength, that could help keep the Christians under Muslim rules, known as the Mozarabs, from converting to Islam. In fact, the opposite occurred. The existence of the Iberian Christian kingdoms, and the ongoing state of war between them and the Muslims, exposed the Mozarabs to the suspicion of being a fifth column. Their typical profile as rural, and thus often religiously poorly educated, communities may have been also a source of vulnerability. ${ }^{17}$ Mikel de Epalza thus suggested that the Christian rural population, isolated from the guidance of the urban clergy, converted more easily to Islam. ${ }^{18}$ The opposite argument is put forward by Wasserstein, who cautiously says that it seems not unlikely that retention of Christianity may have been stronger in the rural areas and in the more isolated parts of the peninsula', and that 'much of the literate class of Christians in al-Andalus went over to Islam'. ${ }^{19}$ But whether more in the cities or more in the countryside, the overall picture remains that conversion was a widespread phenomenon among the Christians, whereas among the Jews it seems to have remained restricted to individual cases.

Religious education in their own tradition may have been one reason for this difference between the two communities. A relatively high level of literacy among Jews, which meant a relatively high level of familiarity with the tenants of

16 See Wasserstein, The Rise and Fall of the Party-Kings, pp. 224-46.

17 The continuous impact of the profile of Visigoth Spain on the Christian ability to adapt to the cultural shock of the Muslim conquest is also noted by John Tolan, Saracens: Islam in the Medieval European Imagination, New York: Columbia University Press, 2002, pp. 85-87.

18 Mikel de Epalza, 'Trois siècles d'histoire mozarabe', Travaux et Jours 20 (1966), pp. 25-40, at p. 29; see also Mikel de Epalza, 'Mozarabs: An Emblematic Christian Minority in Islamic al-Andalus', in Salma Khadra Jayyusi (ed.), The Legacy of Muslim Spain, Leiden: Brill, 1992, vol. I. chap. 12, pp. 149-199. Tolan (Saracens, p. 96) also points to the 'conversion by slippage', a gradual disintegration of Christian communities as a passive reaction to the prevailing circumstances. Scholarly positions regarding the pace and historical context of the conversion of Christians to Islam in the Iberian peninsula are succinctly summarize in Burns, Muslims, Christians, and Jews, pp. 4-5.

19 Wasserstein, The Rise and Fall of the Party-Kings, pp. 229-230 and p. 237. The predominance of provincial communities in preserving religious tradition is attested also in the Genizah documents, according to the analysis of which, as noted by Goitein (Mediterranean Society I, p. 15), 'Hebrew lingered on in the smaller towns of Egypt longer than in the larger centers'. 
Between Acculturation and Conversion on Islamic Spain

their own religion, and a strong, cohesive community, may well have strengthened the ability of Jews to withstand the pressures to convert to Islam. ${ }^{20}$ But a more relevant difference between the two communities seems to be found in another aspect of their education, regarding not their own tradition but that of the surrounding society.

From the eighth century onwards, across the world of Islam, Arabic became the common language of the various ethnic and religious communities, used both for everyday life and for intellectual pursuits. The ubiquity of the use of Arabic created a common culture, covering everything from science and philosophy to belles lettres and personal correspondence. In the Orient, Jews and Christians preserved their religious language, and Hebrew and Syriac continued to be used in limited religious contexts. But both Jews and Christians also fully participated in the common Arabic culture, adopting the Arabic language both as a vernacular and as a cultural language. This meant that, more often than not, Arabic was their own mother tongue, and that they employed it also for their respective religious writings (although often retaining their own script). ${ }^{21}$ Christians in the Orient played a decisive role in shaping this Arabic cultural koiné or common culture, transmitting to the Muslims the philosophical and scientific Greek heritage and translating it to Arabic. From the ninth century onwards, Jews too participated in this common culture and made it their own. Jews developed, in Arabic, new literary genres and new forms of Jewish religious expression. Biblical and Talmudic exegesis, Jewish philosophy, theology, mysticism, Jewish pietistic literature and Jewish law were developed in Arabic, using the same concepts and patterns of thought as their Muslim rulers used for Koran exegesis or for Muslim law.

20 See Haim Beinart, 'Hispano-Jewish Society', in Ben-Sasson and Ettinger, Jewish Society, pp. 220238, at p. 221. According to Beinart, 'the Jewish public in the communities of Moslem Spain... kept to themselves, whether in matters of organization and social structure or in those outward form of life that they adopted in Spanish lands'.

21 On the linguistic aspects of this culture, see Joshua Blau, The Emergence and Linguistic Background of Judaeo-Arabic: A Study of the Origins of Middle Arabic. Jerusalem: Ben-Zvi Institute, 1981; Sidney H. Griffith, The Bible in Arabic: the Scripture of the 'People of the Book' in the language of Islam, Princeton: Princeton University Press, 2013). See also David J.Wasserstein, 'A Family Story: Ambiguities of Jewish Identity in Medieval Islam', in Benham Sadeghi, Asad Q. Ahmed, Adam Silverstein, and Robert Hoyland (eds.), Islamic Cultures, Islamic Contexts: Essays in Honor of Professor Patricia Crone, Leiden: Brill, 2015, pp. 498-532, at pp. 511-514. See also Elaine R. Miller, Jewish Multiglossia: Hebrew, Arabic and Castilian in Medieval Spain, Newark, Delaware: Juan de la Cuesta, 2002), whose main focus is on later periods, under Christian rule. Miller's statement that Jews 'did not study classical Arabic' is probably correct as a general observation regarding the community as a whole. But the educated elite, which did study classical Arabic, may well have included not just courtiers and philosophers, but quite a few others. See also Esperanza Alfonso, Islamic Culture through Jewish Eyes: Al-Andalus from the Tenth to Twelfth Century, New York: Routledge, 2008, pp. 9-33. 
In the Iberian peninsula, however, the difference which we noticed between the two communities, regarding the social-fabric of the communities and their patterns of behavior regarding conversion, is evident also in their level of acculturation. ${ }^{22}$ Jews living in al-Andalus, as elsewhere, adopted Arabic and developed their own, Jewish version of Arabic culture. This applied to all levels of the Jewish community, with the community leaders, who often carried not only political but also religious authority, taking the lead in this process. Jewish intellectuals were active participants in the court culture. A creative Andalusian Judaeo-Arabic culture flourished, and even Hebrew poetry in al-Andalus was shaped in the mold of Arabic poetical styles. The Christians of al-Andalus, on the other hand, unlike their brethren in the Orient, played only a relatively marginal role in the intellectual, cultural and political life in Arabic (with the exception of medicine).$^{23}$ Adoption of the Arabic high literary culture in general among the Andalusi Christians seems to have been a more protracted and tortuous process. ${ }^{24}$ When it finally seems to take root in the more urban segments of the Christian

22 'Acculturation' in this article refers primarily to the literary and verbal expression of culture, those associated with the use of the Arabic language; compare below, note 24 .

23 Wasserstein, The Rise and Fall of the Party-Kings, pp. 244-245, says that Christians scarcely participated in Islamic political life, and attributes it to the fact that they lacked the necessary skills to do so. "The majority of those who did acquire them seem to have ended up as converts to Islam', and the others probably entered the Church. See also Pérès, La poésie andalouse, p. 264, who points out that the Jews 'apprécièrent mieux que les Chrétiens les avantages d'être soumis à de nouveaux conquérants', and that, although many Jews have surely converted to Islam, their favorable place in the Muslim courts must have slowed down the conversions.

24 See Hanna Kassis, 'The Arabicization and Islamization of the Christians of al-Andalus', in Ross Brann (ed.), Languages of Power in Islamic Spain, Occasional Publications of the Department of Near Eastern Studies and the Program of Jewish Studies, Cornell University, 3; Bethesda, Maryland: CDL Press, 1997, pp. 136-155. On the continuous use of Latin and Romance by the Christians of al-Andalus, see, for example, Claudio Sánchez-Albornoz, 'Espagne préislamique et Espagne musulmane', Revue Historique 237 (1967), pp. 295-338, at pp. 301-302; Juan Pedro Monferrer-Sala, 'Les chrétiens d'al-Andalus et leurs manifestations culturelles', in Guy Saupin, Rémi Fabre and Marcel Launay (eds.), La Tolérance. Colloque international de Nantes (mai 1998), Rennes: Presses universitaires de Rennes, 1999, pp. 363-370, at p. 369; Federico Corriente, Romania Arabica: Tres cuestiones básicas: arabismos, "mozárabe” y “jarchas”, Madrid: Trotta, 2008, pp. 9-17; Juan Pedro Monferrer Sala, 'Somewhere in the 'History of Spain'. People, languages and texts in the Iberian Peninsula ( $13^{\text {th }}-15^{\text {th }}$ centuries)', in David Thomas et al. (eds.), Christian-Muslim Relations. A Bibliographical History, Volume 5 (1350-1500), Leiden-Boston: Brill, 2013, pp. 47-59, especially pp. 48-49. Wasserstein (The Rise and Fall of the Party-Kings, p. 238) also notes the eventual Arabisation of the literate classes of the Christians. There were other aspects of acculturation which did have a profound impact on Iberian Christians under Islam, and which found their expression in the material culture, agriculture and water system, legal system, and the vocabulary pertaining to these aspects. See Glick, Islamic and Christian Spain, for example pp. 51, 277-299; Thomas S. Glick and Oriol Pi-Sunyer, 'Acculturation as an Explanatory Concept in Spanish History', Comparative Studies in Society and History 11/2 (1969), pp. 136-154; Novikoff, 'Between Tolerance and Intolerance', p. 29; and see above, notes 7 and 22. 
community, in the first half of the ninth century, the community's religious leaders panic and react with alarm. The Church's resistance to Arabisation, and its attempts to reaffirm a genuinely Christian Latin culture, are evident in the writings of clergymen like Alvarus, Eulogius and Samson. ${ }^{25}$

The differences between the Jews and Christians of al-Andalus, and the connection between their respective level of acculturation and their respective level of conversion, have of course been noticed by scholars. Wasserstein points to the emergence of a distinct Judeo-Arabic culture and argues that, across the Islamic medieval world,

'it was the possession of a distinct and separate culture that gave the Jews an identity which enabled them to retain their distinct religion and to avoid absorption into the broader society'. ${ }^{26}$

David Abulafia addressed this issue specifically regarding the Iberian peninsula, noting the fact that 'Jews in al-Andalus and elsewhere did not follow the same path as the Mozarabic Christians in Islamicizing themselves. Or, more simply: the Jews Arabized but did not Islamize.' For Abulafia,

'the rather open society of Muslim Spain managed to undermine Christianity, while... strengthening Judaism. .... The mystery of why the Jews acculturated but did not assimilate to Islam, as did many Christians, finds its answer in the existence of [the] common ground that existed between Judaism and Islam in this society. ${ }^{27}$

25 The anxiety caused by the accelerated pace of Arabisation is clearly expressed by Alvarus; see, for example, Francisco Javier Simonet, Historia de los Mozarabes de España, Madrid: Turner, 1983, vol. II, pp. 369-371; Sidney H. Griffith, The Church in the Shadow of the Mosque: Christians and Muslims in the World of Islam, Princeton, Princeton University Press, 2008, p. 152; Tolan, Saracens, pp. 86, 95-96.

26 Wasserstein, 'Islamisation and the Conversion of the Jews', p. 57.

27 David Abulafia, 'What Happened in al-Andalus: Minorities in al-Andalus and in Christian Spain', in Sadeghi et al., Islamic Cultures, pp. 533-50, at pp. 540-541. Abulafia adds another explanation, which relates to the different character of Islam and Judaism on the one hand and Christianity on the other. According to him, "perhaps Christianity was less resilient because in the early Middle Ages it provided a spiritual and ritual framework, but did not provide a detailed code of religious practice to determine conduct hour by hour'. The central role played by steadfast intellectual identity and by having a common ground with Islam (or the lack thereof) is also noted by Thomas Burman (Religious Polemic and the Intellectual History of the Mozarabs). Another explanation for the disappearance of Christian communities and the survival of Jewish communities is offered by Goitein ('Jewish Society and Institutions under Islam', pp. 174-75), who points out 'the ecology of Jews under Islam, i.e. their topographical distribution'. Goitein, however, focuses on the example of Yemen, where the Jewish population was widely dispersed, and where the Christians were concentrated in the cities. In al-Andalus, as mentioned above, the opposite was the case. Another major difference between the two minority communities in 
Up to this point, we focused on the conversion and acculturation patterns of the two communities as a whole. Putting it, again, bluntly: the Christians of alAndalus converted to Islam, the Jews of al-Andalus became culturally arabicized but did not convert. ${ }^{28}$ Communities, however, are made of individuals, and when we examine individuals, we find that the dichotomy between conversion and acculturation cannot be so neatly delineated. As noted in contemporary immigration studies,

'acculturation is something akin to conversion, i.e. a departure from one group and a discarding of signs of membership in it, lined to an attempt to enter into another. ${ }^{29}$

The boundary blurring that occurs in this process creates blurred cases, and each such case deserves to be examined separately. The valiant attempts to offer statistics and draw curves that describe the conversion process cannot, I believe, replace the close examination of individual cases. This is so not only because of the reservations expressed by various scholars regarding the reliability of quantitative methods in our present state of knowledge. ${ }^{30}$ Even if the quantitative method could rely on a larger relevant database than it currently does, individual, anecdotal cases highlight nuances that the quantitative method by its very nature obscures. It is one such case, or rather a cluster of cases, on which I would like to focus now.

This is the complex case of five generations of one Jewish family, five men all of whom can be considered to have belonged to the intellectual and social elite of the community. Although much has been written about them as individuals,

al-Andalus was the possibility of moving to a neighboring coreligionist polity, which was available for Christians but not for Jews. This difference, however, can partly account for the disappearance of certain Christian communities, but not (or at least, not directly) for the conversion of those who remained under Islamic rule.

28 But see Hirschberg, A History of the Jews in North Africa, vol. I, p. 191; García-Arenal, 'Rapports entre les groupes', p. 94.

29 Richard Alba, 'Bright vs. Blurred Boundaries: Second-Generation Assimilation and Exclusion in France, Germany and the United States', Ethnic and Racial Studies 28 (2005), pp. 20-49, at p. 24; quoted in Jürgen Gerhards and Silke Hans, 'From Hasan to Herbert: Name-Giving Patterns of Immigrant Parents between Acculturation and Ethnic Maintenance', American Journal of Sociology 114 (2009), pp. 102-28, at p. 118. I am indebted to Jürgen Gerhards for bringing this study to my attention. On the 'permeable, fluid and constantly renegotiated' boundaries of religious groups in the period which concerns us here, see also Papaconstantinou, 'Between Umma and Dhimma', pp. 130-131.

30 See, for example, Penelas, 'Some remarks on Conversion'; Wasserstein, 'Where have all the converts gone?', p. 326, n. 1, and p. 327. 
their very description as five generations of a single family is not unanimously agreed upon. As we will presently see, some scholars do not identify all five as belonging to the same family, while others skip one generation or identify two members as being one and the same person, thus telescoping the five generations to four or even three. ${ }^{31}$ The family prided itself of being direct decedents of the Prophet Moses. ${ }^{32}$ The first member of the family that concerns us here is the physician and statesman Hasday ibn Shaprūt (ca. 910-ca. 970). ${ }^{33}$ Born into a wealthy and respectable Jewish family from Jaén, which then moved to Córdoba, he served as the court physician and vizier of the first Umayyad Caliph, 'Abd alRahmān III, as well as of his son al-Hakam II. Due to Ibn Shaprūṭ's multilingual aptitude and political talents, he was employed in the Caliphs' service carrying out delicate diplomatic assignments, as well as in more specific academically oriented missions, such as the massive importation of books from the Orient, or the translation of Dioscorides' De Materia Medica into Arabic. ${ }^{34} \mathrm{He}$ was also the

31 See below, nn. 32-33, 41.

32 This ancestry is mentioned only regarding Abū'l-Fadl Hasday, the third generation of the family; on the identity of his father and grandfather, see further below. Wasserstein regards the claimed Mosaic lineage as a mistake, the result of Ibn Șā'id's presuppositions regarding what a noble Jewish line should be. Wasserstein further suggests that Moses should be corrected to David, since the claim for belonging to a Davidic line is by far more common in Jewish genealogies. As in the best practice regarding the edition of manuscripts, here too the rule of lectio difficilior should be adopted. In additions to this technical argument in favor of the name Moses, we should take into account Ibn Sāa'id's close connections with Abū'l-Fadl Hasday, Ibn Shaprūt's grandson; see below, note 33. These connections make it more than probable that he knew the family well and was familiar with the family tradition of its Mosaic ancestry. Furthermore, it seems that, perhaps in al-Andalus in particular, Moses's name was invoked rather fondly. Thus Ibn Daud says about Joseph Ibn Megash that 'his personal traits testified that he was of the seed of our master Moses... since he was the most humble of man' (in reference to Num. 12.3); see Abraham Ibn Daud, The Book of Tradition (Sefer ha-Qabbalah), ed. Gershon D. Cohen, Philadelphia: the Jewish Publication Society, 1967, p. 86. What appears to be the rather unusual name given to Moses Maimonides should perhaps also be seen in this context; see I. Yuval 'Moses Redivivus; Maimonides as the Messiah's Helper', Zion 72/2 (2007), pp. 161-188 (in Hebrew).

33 Wasserstein, who mentions the Ibn Hasday family of Saragossa as one of two rare cases where we have records of Jewish dynasties in al-Andalus, does not connect them to Hasday Ibn Shaprūț; see David Wasserstein, 'Jewish Élites in al-Andalus', in Daniel Frank (ed.) The Jews of Medieval Islam: Community, Society and Identity, Leiden: Brill, 1995, pp. 101-110, at p. 109. For that matter, nor does Ibn Șāi id, who does not mention at any point a family connection between Hasday Ibn Shaprūt and the Saragossan descendant of Moses, Abü'l Faḍl Ibn Hasday. But as noted by Wasserstein, Ibn Shaprūt is the only Jew outside of Saragossa mentioned by Ibn Șā id. This fact is best explained as reflecting the information he had received from the young Abü' 1 Fadl regarding his family, and, by the same token, corroborates Abü'l Fadll's connection to Ibn Shaprūṭ.

34 On the role of Jews in medieval international diplomacy, see Nikolas Jaspert and Sebastian Kolditz, 'Christlich-muslimische Aussenbeziehungen im Mittelmeerraum. Zur räumlichen und 
recognized head (nassi) of the Jewish community, and he used his international connections on behalf of Jewish communities across the Mediterranean. ${ }^{35}$ Hasday ibn Shaprūt is thus an emblematic acculturated Jewish dignitary of al-Andalus, navigating at ease in the Muslim corridors of power and intellectual salons, and at the same time deeply rooted in his own tradition. Ángel Sáenz-Badillos thus describes him as 'one of the personalities... [who] contributed most directly to the emergence and rapid maturation of a genuinely Andalusi Jewish culture'. ${ }^{36}$

After Hasday ibn Shaprūṭ's death, and after the disintegration of the Umayyad Caliphate of Cordoba, the family left Cordoba and moved, via Granada, to Saragossa in the north of the peninsula. Ibn Shaprūt's offspring seem, at first sight, to follow in his footsteps, integrating the two worlds in which they lived. His eldest son, Abū al-Walīd Hasday, replaced him as head ( $r a$ 'is) of the Talmudic academy in Lucena. ${ }^{37}$ Another son, Abū 'Amr Yūsuf, served at the courts of Granada, then Sahla (Albarracín) and finally Saragossa, and is also known to have been a talented Hebrew poet. ${ }^{38}$ Ibn Shaprūṭ's grandson, Abū'l-Faḍl Ḥasday ibn

religösen Dimension mittelalterlicher Diplomatie', Zeitschrif für historische Forschung 41 (2014), pp. $1-88$, at p. 39 .

35 Further on Ibn Shaprūt, see, for example, Philoxène Luzzatto, Notice sur Abou-Iousouf Hasdaï ibn Schaprout, Médecin juif du dixième siècle, ministre des khalifes omeyyades d'espagne 'Abd-al-Rahman III et al-Hakem II, et promoteur de la littérature juive en Europe, Paris: Dondey-Dupré, 1852); Solomon Munk, Mélanges de philosophie juive et arabe, Paris: A. Franck, 1859; reprinted Paris: Vrin, 1988, pp. 480-481 and note 2; Yitzhak Baer, A History of the Jews in Christian Spain, Philadelphia: Jewish Publication Society, 1961, vol. I, p. 16, and note 7 on p. 382; Jacob Mann, 'Hisdai Ibn Shaprūṭ and his Diplomatic Intervention on Behalf of the Jews in Christian Europe', Texts and Studies in Jewish History and Literature, New York: Ktav, 1972, vol. I, pp. 3-30; Haim Beinart, Los Judíos en España, Madrid: MAPFRE, 1992, pp. 50-52; Ibn Șā'id, Țabaqāt al-Umam, ed. Bū 'Alwān, Beirut: Dār alțalī'a, 1985), p. 203, line 13-204, line 6; Ibn Abī Ușaybi 'a, 'Uyūn al-Anbā' fì Ṭabaqāt al-Ațibbā' , ed. Nizār Rị̣ā, Beirut: Maktabat al-ḥayāt, n.d.), p. 498; Sarah Stroumsa, 'Thinkers of 'This Peninsula': An Integrative Approach to the Study of Philosophy in al-Andalus', in D. Freidenreich and M. Goldstein (eds.) Border Crossings: Interreligious interaction and the exchange of ideas in the Islamic Middle Ages, Philadelphia: University of Pennsylvania Press, 2012, pp. 44-53, at pp. 49-51.

36 Ángel Sáenz-Badillos, Literatura Hebrea en la España Medieval, Madrid: Fundación Amigos de Sefarad, 1991, p. 21.

37 See Moses Ibn Ezra, Kitāb al-Muhā Consejo Superior de Investigaciones Cientificas, 1985, vol. I, p. 65.

38 Moses Ibn Ezra (Muhädara, vol. I, pp. 74-75), who counts him among the inhabitants of sharq alandalus, evaluates his output as 'little but to the point (qawluhu qali lakinnahu jalil)'. He is said to have dedicated a qasiida to Samuel ha-Nagid, known as the 'shira yetoma' (= yatima); see Judah Alharizi, Tahkemoni or The Tales of Heman the Ezrahite, ed. Joseph Yahalom and Naoya Katsumata, Jerusalem: Ben Zvi Institute, 2010), III, pp. 112, 174; Eliyahu Ashtor, the Jews of Moslem Spain, Philadelphia: The Jewish Publication Society, 1984, vol. II, p. 258; Sáenz-Badillos, Literatura Hebrea, p. 113. See also Á. C. López y López, 'Ibn Ḥasdāy, Abū l-Faḍl', Biblioteca de al-Andalus, ed. Jorge Lirola Delgado and José Miguel Puerta Vílches, Almería: Fundación Ibn Tufayl de Estudios Árabes, 2004, vol. III, pp. 303-309, at 304. Beinart, Los Judíos en España, p. 60, which mentions 
Between Acculturation and Conversion on Islamic Spain

Yūsuf, was thoroughly trained as a philosopher, and was also an accomplished poet in both Hebrew and Arabic; ${ }^{39}$ but he also attended the court of the Banū Hūd of Saragossa, serving al-Muqtadir ibn Hūd (r. 438/1046-475/1082-83) as well his son al-Mu'taman (r. 475/1082-478/1085) and grandson al-Musta ìn (r. 478/1085503/1110) after him. ${ }^{40}$ His own grandson, (the great-great-grandson of Ibn Shaprūt), Abū Ja far Yūsuf bn. Ahmad bn. Ḥasday, immigrated at some point to Egypt, from whence he kept a close correspondence with a Muslim friend, the Saragossan philosopher Ibn Bājja (d. 533/1138). ${ }^{41}$ This Abū Ja far is known to have specialized in the study of medicine, and was asked by al-Ma'mūn al-Bațā' iḥī, who served between 515/1122 and 519/1125 as the vizier of the tenth Fätimid Caliph, al-Āmir bi-aḥkām Allāh (d. 524/1130), to write commentaries on the writings of Hippocrates and Galen. ${ }^{42}$ The record of the family members thus clearly testifies that they followed the example of their ancestor Hasday ibn Shaprut in their cultural refinement and their interest in things intellectuals as well as in their connection to the Muslim ruling class.

But the religious identity of Hasday ibn Shaprūt's descendants is anything but clear. On the one hand, they are designated as Jews, by both Muslim and Jewish sources. On the other hand, for each one of them we also have sources reporting,

Joseph as Hasday's son, is a slip of the pen, and should of course be corrected to Samuel haNagid's son.

39 Ibn Ezra, Muhāọdara, vol. I, p. 75: '...aljama al-adawāt al- 'ilmiyya, al-kāmil al-șinā'a al-falsafiyya, almuwaffi li-' l-aqāwill al-shi 'riyya wa' l-khițabiyya fìl- 'ibrāniyya wa 'l- 'arabiyya.' See also Ashtor, The Jews of Moslem Spain, vol. III, n. 117 on p. 295; Ibn Șā id, Ṭabaqāt al-umam, p. 205, line 8-p. 206, line 6; Ibn Abī Ușaybi 'a, 'Uyūn al-anbā', p. 499; López y López, 'Ibn Ḥasdāy, Abū l-Faḍl', pp. 304-305.

40 See Wasserstein, The Rise and Fall of the Party-Kings, pp. 211-212,

${ }^{41} \mathrm{Abu \overline { } \mathrm { Ja }}$ 'far Yūsuf is thus the grandson of Abū'l-Faḍl Hasday (as noted correctly in the table drawn by López y López, 'Ibn Hasdāy, Abū l-Fadll', p. 306, and not his son (as mistakenly noted by López y López, 'Ibn Ḥasdāy, Abū l-Faḍl', p. 307). On him, see also Pérès, La poésie andalouse, pp. 266-267. A suggestion that Abū Ja 'far actually was Abü'l-Faḍl's son was put forward by Shlomo Pines, "La dynamique d'Ibn Bājja", Mélanges Alexandre Koyré, Paris: Hermann, 1964, vol. I, pp. 442-68; reprinted in The Collected Works of Shlomo Pines, Jerusalem: Magnes, 1986, vol. II, pp. 44068. A still further telescoping of these three individuals, identifying Abū Ja 'far Yūsuf with Abü'lFaḍl Ḥasday, as one and the same person, was suggested by Juan Vernet Ginés, La transmisión de algunas ideas cientificas de oriente a occidente y de occidente a oriente en los siglos XI-XIII, Rome: Unione internazionale degli institute de archeologia, storia y storia dell'arte in Roma, 1992, pp. 25-31 (non vidi); see Miquel Forcada, 'Ibn Bājja and the Classification of the Sciences in alAndalus', Arabic Sciences and Philosophy 16 (2006), pp. 287-307, 296.

${ }^{42}$ See Rasā'il falsafiyya li-Abī Bakr bn. Bājja: nușūṣ falsafiyya gayr manshūra, ed. Jamāl al-Dīn al- 'Alawī, Casablanca: Dār al-nashr al-maghribiyya, 1983, p. 77 and note 1; Ibn Abī Ușaybi'a, 'Uyūn alanbā', p. 500; López y López, 'Ibn Ḥasdāy, Abū Ŷa 'far', Biblioteca de al-Andalus, vol. III, pp. 309310. On al-Ma'mūn al-Bațā' ihī's scientific ambitions, see also P. E. Walker, 'Fatimid Institutions of Learning', Journal of the American Research Center in Egypt 34 (1997), pp. 179-200 (reprinted in P. E. Walker, Fatimid History and Ismaili Doctrine, Aldershot: Ashgate-Variorum, 2008, p. 198, n. 1). 
or modern scholars arguing, that he was the one who broke away from Judaism and converted to Islam. It is not only that they themselves, despite their supposed conversion, continue to be designated as Jews, or as of Jewish origin. ${ }^{43}$ What is really puzzling is the fact that despite their supposed conversion, their offspring, for three generations, are also said to have taken at some point the step of converting, implying that they were born and raised as Jews. Conversion in this family thus does not look as a one time transformative event, nor even as a process in the life of the individual that at some point reaches its end, but rather as a perpetuum mobile.

The examination of each of these cases shows contradictory information that does not help us clarify the picture. Let us quickly run through these cases:

$2^{\text {nd }}$ generation: Hasday ibn Shaprūṭ's son Abū 'Amr Yūsuf is sometimes identified as the addressee of a satirical poem by Abū'l-Rabī' Sulaimān bn. Ahmad al-Quḍā' $\mathbf{1}$, directed at a certain Yūsuf al-Islāmī (an appellation that supposedly means 'the convert') and referring obliquely to 'he who joins a religious community'. ${ }^{44}$ Yūsuf's conversion is supposed to have taken place when he reached old age, along with the conversion of his grown son Abü' l-Fadll. ${ }^{45} \mathrm{But}$ the dates do not fit this scenario, since a note by the Jewish grammarian Ibn Janāh (written ca. 1048) refers to him with the blessing rahimahu 'Alläh, and it thus appears that Yūsuf must have died shortly after this son's birth. ${ }^{46}$

43 As Wasserstein points out, the appellation al-Isrā 'illi, which is appended to names of Jews, could also be appended to that of converts from Judaism (unlike al-yahūdī, reserved for actual Jews); see D. J. Wasserstein, 'What's in a Name? 'Abd Allāh b. Isḥāq b. al-Shanā'a al-Muslimānī alIsrā'îlì and Conversion to Islam in Medieval Cordoba', in Arnold E. Franklin, Roxani Eleni Margariti, Marina Rustow, and Uriel Simonsohn (eds.), Jews, Christians and Muslims in Medieval and Early Modern Times: A Festschrift in Honor of Mark R. Cohen, Leiden: Brill, 2014, pp. 139-154, at p. 146. One should also note that, when the name of a person appears with his patronym or with a longer genealogical line, the epithet al-Isrā ìli, which appears at the end of the list, might refer to the Jewish forefather rather than to the person himself.

${ }_{44}$ 'Man dakhala fì millatin...'; Abū al-Ḥasan 'Alī al-Santarīnī Ibn Bassām, Al-Dhakhīra fì mahāāin ahl aljazìra, ed. Sālim Muștafāa al-Badrī, Beirut: Dār al-kutub al-'ilmiyya, 1998, vol. III, pp. 314-317. See Pérès, La poésie andalouse, p. 266, n.1; and, more explicitly, López y López, 'Ibn Ḥasdāy, Abū lFadl', p. 307. Ashtor, on the other hand, clearly regards this Yūsuf as unrelated to Hasday's son; see Ashtor, The Jews of Moslem Spain, p. 191. See also Wasserstein, The Rise and Fall of the PartyKings, p. 211; and apparently also García-Arenal, 'Rapports entre les groupes', p. 95. On the appellation 'al-Islām $\vec{\imath}$ ' as the proper way to designate a convert, see also Penelas, 'Some remarks on Coversion', p. 199.

45 See Ibn Dihya, Al-Muțrib min ash ār ahl al-maghrib, ed. Ibrāhīm al-Abyārī, Ḥamīd 'Abd al-Majīd and Aḥmad A. Badawī, Cairo: al-Maṭba' a al-āmīrīyya, 1954, pp. 196-97 (= ed. Mușțafā 'Iwaḍ alKarīm [Khartum: Maṭba at Miṣr, 1957], p. 179); López y López, 'Ibn Ḥasdāy, Abū l-Faḍl', pp. 305306; Wasserstein, The Rise and Fall of the Party-Kings, pp. 211-212.

46 Yonah Ibn Janāḥ, Sefer ha-Riqma (Kitāb al-luma' ), ed. M. Vilenski, Jerusalem: The Israel Academy of Sciences and Humanities, 1964, p. 319; Abū'l-Walīd Marwān Ibn Janāḥ, Kitāb al-luma ; ed. 
$3^{\text {nd }}$ generation: That son, the young Abū'l-Faḍl Hasday ibn Yūsuf, is described by the Muslim historian Ibn șā id (who met him and apparently befriended him, despite their age-difference, in Saragossa) as a brilliant Jewish boy. Ibn șā id counts him as one of the only three Andalusians in his knowledge who engaged in the study of physics and metaphysics. ${ }^{47} \mathrm{He}$ further declares that Abü'l-Fadl's level in the theoretical sciences was unequalled in al-Andalus. ${ }^{48}$ But Ibn Șā id, writing in Toledo in 464/1067, knows nothing (yet?) about his conversion. ${ }^{49}$ Another source, however, Ibn Dihya (d. 633/1235-36, who follows Ibn Khaqān), says that he did convert, because being a dhimmi was a disadvantage among his Muslim peers..$^{50}$ Yet another medieval source, Ibn Bassām, reports that Abū'l-Faḍl converted to Islam because he fell in love with a slave girl; when, however she

Joseph Derenbourg, Paris: E. Vierweg, 1886, p. 304; Ashtor, The Jews of Moslem Spain, n. 84 on p. 250.

47 Ibn Șā'id, Tabaqāt al-umam, p. 185; compare the French translation of Régis Blachère, Kitâb Tabakât al-Umam (Livre des Catégories des Nations), Paris: Larose, 1935, p. 142, and the English translation of Sema'an I. Salem and Alok Kumar, Science in the Medieval World: 'Book of the Categories of Nations' by Șā 'id al-Andalusī, Austin: University of Texas Press, 1996, p. 71 and pp. 198-199.

48 'Mahalluhu min al- 'ulūm al-nazariyya al-mahall alladhī lā yujārī 'indanā fìl-andalus'; Ibn Ṣā'id, TTabaqāt al-umam, p. 172. Blachère, Livre des Catégories des Nations, p. 132, understands this last sentence as referring to Abū' l-Hakam al-Kirmānī (d. 458/1066), mentioned shortly beforehand, and translates: 'Par contre, dans les sciences spéculatifs il n'avait point d'égale en Andalousi'. A similar understanding is reflected in the English translation of Salem and Kumar, Science in the Medieval World, p. 65: 'He knew him [scil. al-Kirmānī) well and he knew his level as a theoretical scientist'. Both translations thus assume al-Kirmānī's superior knowledge. But as Ibn Șā'id's previous lines explicitely say, al-Kirmānī's forte was in the applied sciences, such as geometry and surgery, and not in the theoretical sciences, such as logics and mathematical astronomy. Hasday, on the other hand, is one of the only three Andalusians mentioned by Ibn Sāa id as students of physics and metaphysics; see previous note.

49 See Ibn Șāid, Tabaqāt al-Umam, pp. 172, 205-206; cf. Wasserstein's translation of this last passage, 'The Muslims and the Golden Age of the Jews in al-Andalus', in U. Rubin and D. J. Wasserstein (eds.) Dhimmis and Others: Jews and Christians and the World of Classical Islam. Israel Oriental Studies 17 (1997), pp. 179-196, at p. 191; and see also Ibn Abī Ușaybi 'a, 'Uyūn al-Anbā', who is dependent on Ibn Șā'id. Wasserstein, 'What's in a Name', points out that Ibn Sa 'îd (alMughrib fi hulā al-Maghrib, vol. II, p. 441, no. 627) calls him al-isrā' ìli, but still assumes that he did convert to Islam. Abū'l-Faḍl's contemporary Ibn Șā'id, however, specifically lists him among the philosophers of the Jewish community (al-Yahüd). When they last saw each other, in 1065, the young Abū'l-Faḍl was clearly (still?) a Jew.

50 'Wa-kānat al-dhimma tuq 'iduhu 'an marātib akfā' ihi, wa-tajiddu fì tumūs rasmihi, hattā alhaqahu 'llāh bi-aqrānihi, wa-aqālahu min muta'aththir khusrānihi, fa-tațahhara wa-aslama, wa-āmana biMuhammad șl 'm'; Ibn Dihya, Mutrib, pp. 196-99 (= p.179 in al-Karīm's edition); al-Fath b. Muḥammad Ibn Khāqān, Qalā'id al- 'Iqyān, Cairo: Būlāq, 1284H, p. 182. Ibn Dihya does not say at what age he converted; compare Wasserstein, The Rise and Fall of the Party-Kings, pp. 211-212. See also Pérès, La poésie andalouse, p. 267. 
was given to him after his conversion, he rejected her because he did not want people to say that his conversion was wrongly motivated and disingenuous. ${ }^{51} \mathrm{Ibn}$ Bassām also recounts another anecdote, in which Abū'l-Faḍl's rival, the vizier Abū al-Muțarrif Ibn al-Dabbāgh, saw him at some point after his conversion to Islam leafing through a book in the presence of al-Muqtadir, and asked him deridingly if it was the Torah that he was reading. Unfazed, Abü'l-Faḍl answered in the affirmative, and added a hint to his rival's low ancestry (Ibn al-Dabbāgh being the son of a simple tanner)..$^{2}$ In yet another exchange, the same Ibn alDabbāgh asked Abū'l-Faḍl sarcastically if he intended to inherit the office of Qādi of Saragossa. ${ }^{53}$ In both anecdotes Ibn al-Dabbāgh obviously alluded to Abū' l-Faḍl's Jewish origins, but whereas Henri Pérès and López y López interpret these allusions as just that - allusions to his origins, notwithstanding his conversion Eliyahu Ashtor regards them as a proof that he was still a Jew. For Ashtor, the rumors that he had converted to Islam were the work of Muslim zealots "who could not reconcile themselves to the elevation of a Jew to the rank of vizier'. ${ }^{54}$

$4^{\text {th }}$ generation: Of Abü'l-Fadl's son we know next to nothing. The Muslim historian al-Maqrīzì calls him 'al-isrā'îli' and gives his name as Ahmad, claiming that he converted to Islam (again, although supposedly his father and grandfather had already converted before he was born). ${ }^{55}$ According to the theory of Richard Bulliet, converts tend to give their children typically Muslim names (although it is also common for converts to change their own names), which would suggest that this Ahmad was already the son of a convert, and that it was his father, Abü'l-Fadl, who converted to Islam. ${ }^{56}$ But Bulliet's theory is meant to describe a phenomenon that can be observed when examining developments on a large scale, and not as a categorical rule that applies to all individual cases. There can thus be cases of a convert choosing for himself a more Muslim name. On the other hand, as noted by Wasserstein, 'in Spain perhaps

51 Ibn Bassām reports that he 'discarded his religion for her sake (khala 'a ilayhā dinnahu)' but then became ambivalent towards her, 'anafatan min an yazunna al-nāsu anna islāmahu kāna min ajlihä'. As a result, his reputation remained good, and many people remained ignorant of his affairs ('wa-khafiya 'alā kathīr min al-nās amruhu); Dhakhïra, vol. III, pp. 290-91; al-Maqqarī, Nafḥ al-țīb min ghuṣn al-andalus al-rațīb, ed. Iḥsān 'Abbās, Beirut: Dār Șādir, 1968, vol. III, pp. 293, 401. It seems that Ibn Bassām too is aware of rumors that deny his conversion, and tries to explain their persistence. The reliability of the story is rejected also by Pérès, La poésie andalouse, p. 267.

52 Al-Maqqarī, Nafh al-tîib, vol. III, pp. 401-402; Pérès, La poésie andalouse, p. 267; Perès, Esplendor, pp. 272, 371 n. 46, 454; López y López, 'Ibn Ḥasdāy, Abū l-Faḍl', p. 306.

53 Pérès, La poésie andalouse, p. 267 and n. 5; García-Arenal, 'Rapports entre les groupes', p. 94.

54 Ashtor, The Jews of Moslem Spain, p. 220.

55 On the use of the appellation 'al-isrā' $i \vec{l}$ ', typically attached to the names of Jews only in a Muslim context, see Wasserstein, 'What's in a Name', pp. 142-146; and see above, nn. 43 and 49.

56 See Bulliet, Coversion to Islam; Wasserstein, 'Where have all the Converts Gone?', pp. 338-339. 
Between Acculturation and Conversion on Islamic Spain

more than elsewhere, there is the additional phenomenon of Muslim names appearing among non-Muslims' ${ }^{57}$ Ahmad's name in itself thus cannot help us determine whether he or his father converted to Islam. From an explicit marginal note by al-Maqrīzi, it appears that Ahmad himself was the one who converted. ${ }^{58}$

$5^{\text {th }}$ generation: The most puzzling case is that of Ahmad's son, Abū Ja far Yūsuf bn. Ahmad bn. Hasday (d. 517/1123). The historian of the physicians Ibn Abi Ușaybi' a says nothing about his religious identity, ${ }^{59}$ whereas al-Maqrīzì describes him as a son of a convert, supposedly born already as a Muslim. ${ }^{60}$ Yet for an unknown reason al-Maqrīiìs modern editors decided to add a word to alMaqrīzìs text, so that in the published text he is said to have converted after arriving in Egypt. ${ }^{61}$

The two members of this family mentioned last are not present at all in Jewish sources, which suggests that their ties with the Jewish community were indeed weak, if not totally severed. In the case of those family members who are mentioned in Jewish sources, nothing is said about their undergoing an act of conversion. Jewish sources in general are loth to mention conversion or criticize the converts, especially in the case of forced conversion. But in our case, the silence is not complete: the fifteenth-century Jewish historian Sa' adya ibn Danan (d. ca. 1495) explicitly addresses the claim of the Muslim sources regarding the conversion of Ibn Shaprūț's grandson Abü'l-Faḍl, and presents it as a baseless claim of the Muslims. ${ }^{62}$ Nor can we neatly divide the sources to Jewish ones, for

57 Wasserestein, The Rise and Fall of the Party-Kings, p. 226.

58 See below, note 60 .

59 Ibn Abī Ușaybi'a, 'Uyūn al-Anbā', pp. 499-500. Ibn Abī Ușaybi a lists him immediately after his Jewish forefathers; but while in their case he depends on Ibn Șā' id, here he seems to have quite a lot of first hand information.

60 See Ahmad ibn 'Alī al-Maqrīzì, Itti 'āz al-Hunafā' bi-Akhbār al-A 'imma al-Fāțimiyyīn al-Khulafā', ed. Jamāl al-Dīn al-Shayyāl and Mahmūd Ḥilmī Muhammad Aḥmad, Cairo: al-Majlis al-a 'lā li' lshu' ūn al-islāmiyya, 1973, vol. 3, p. 94 and n. 1 (= Itti 'āz al-hunafä' of Taqī al-Dìn Ahmad al-Maqrīzì, ed. Ayman Fu'ād Sayyid [London: Institute of Ismaili Studies, 2010], vol. 3, p. 110 and n. 1). The Istanbul manuscript is copied from an autograph manuscript which had a marginal note in alMaqrīzì's hand, and which reads: wa-aslama abūhu.

61 This unexplained, and obviously erroneous addition, which was introduced first in the Egyptian 1973 edition of al-Maqrīzī (vol. 3, p. 94), was then repeated in Ayman's newer edition (see previous note). I am indebted to Paul Walker who brought this curious note to my attention, and generously put a copy of the relevant page of the Istambul manuscript at my disposal.

62 See 'She'ela 'al dvar ha'anusim', Fas ve-Hakhameha, Jerusalem: Beit 'Oved, 1969, vol. II, p. 7 (in Hebrew); Ashtor, The Jews of Moslem Spain, pp. 221-222. Wasserstein (The Rise and Fall of the PartyKings, p. 212) dismisses this denial as inspired more... by horror at the idea of a distinguished member of a family which claimed priestly descent converting than by any real evidence to the contrary'. But there were other Jews of distinguished families who converted to Islam (some of whom mentioned by Wasserstein), and whose conversion Ibn Danan did not bother to contest, 
whom the persons discussed here remained Jews, and Muslim sources, who maintain that they have converted to Islam. For, as we have just seen, the Muslim sources themselves are full of contradictions in this regard.

There are several possible explanations for this rolling confusion (in addition to the confusing effect of the similar names, what we may call an embarras de Hasdays). The simplest is to ignore the confusion and to say that one or another of this second, third, fourth and fifth generations of Arabicized Jews did indeed convert to Islam, in his own specific circumstances and for his own reasons. Conversion, then, becomes the final expression of acculturation and its concluding step. ${ }^{63}$ This explanation is the one adopted by scholars like Henri Pérès, García-Arenal, López y López and Wasserstein. ${ }^{64}$

Another explanation of the contradictory information in our sources would be that, in that religious age, the religious identity of the highly acculturated Jewish dignitaries who did not convert to Islam presented a puzzle to their contemporary fellow Muslims or to later historians, and was misunderstood to mean that they actually converted. This is the approach adopted by Ashtor, Abraham Shalom Yahuda and Izhak Baer. ${ }^{65}$ If we take this explanatory path, we would have to say that in some cases, conversion is in the eye of the beholder.

Both these explanations assume that some of the sources are right and others are wrong, and that a person can either remain a Jew or convert to Islam, but not both. There is, nevertheless, also a third possibility, which is suggested by the curious hybrid appellation 'al-Muslimāni al-Isrā 'ill' which we find attached to the name of a Jewish physician, a certain 'Abd Allāh, in Ibn Șā'id's Annales. ${ }^{66}$ 'Hybridity' does not necessarily mean ambiguity; as noted by Wasserstein, in this

although his horror must have been just as great. Furthermore, Ibn Danan also mentions the North African eleventh-century Dūnāsh Ibn Tamīm as someone who, according to what the Muslims say, have converted to Islam, and in this case, Ibn Danan, rather than silencing a horrifying rumor, is the only source to record this claim.

63 See García-Arenal, 'Rapports entre les groupes', p. 92; M. Fierro, 'Cuatro preguntas en torno a Ibn Ḥafșūn', Al-Qanțara 16 (1995), pp. 221-257, especially p. 238.

64 Pérès, La poésie andalouse, pp. 264, 267; García-Arenal, 'Rapports entre les groupes', p. 94; M. García-Arenal, 'Jewish Converts to Islam in the Muslim West', in Rubin and Wasserstein, Dhimmis and Others, pp. 227-248, at p. 233; Wasserstein, 'What's in a Name'; López y López, 'Ibn Hasdāy, Abū l-Faḍl', pp. 305-306 (referring to Perès, Esplendor, p. 272).

65 Abraham Shalom Yahuda, 'Ḥisdai b. Joseph b. Hisdai', in Ever ve- 'Arav, New York: 'Ogen, 1946, pp. 113-18 (in Hebrew).

${ }^{66}$ Ibn Șā'id's, Țabaqāt al-umam, p. 192. The case is discussed in Wasserstein, 'What's in a Name?' pp. 139-154. As noted by Wasserstein ('What's in a Name?', pp. 140, 147-151), as the epithets follow the personal name as well as the patronym, it is impossible to determine whether the convert was the father or the son. The term al-muslimāni, although quite rare, clearly indicates a convert to Islam; see Wasserstein, 'What's in a Name?', p. 142 and note 9 on p. 146 (following Dozy, Suppléments, I:679). See also Zorgati, Pluralism, especially pp. 176-177. 
case, the combination of the two appellations is precisely intended to be unambiguous in indicating a former Jew who converted to Islam. ${ }^{67}$ But the insistence on mentioning these two appellations together, calling him 'alMuslimāni al-Isrä îli , probably does not come from the wish to be precise, but rather as a put down. It seems indeed that, when high dignitaries like the Ibn Hasday family did convert to Islam, their Jewish origins were not forgotten and their identity remained colored, not to say tainted, by these origins. The contradictory information in our sources can thus reflect the ambivalent attitude, or the uncertainty, regarding a liminal religious identity. ${ }^{68}$

In describing the converts' position as 'liminal' I mean to indicate first of all the fact that their new coreligionists did not trust the sincerity of their conversion. They were treated, in some sense, as being on probation, hanging on the margin of their new community. To be sure, such mistrust of new converts was very common; it is reflected in the anecdote recounted above, regarding Abü'l-Faḍl Hasday's anxiety lest his conversion be attributed to such base motives as the infatuation with a slave girl. It is also reflected in the insistence of some Muslim sources to clearly spell out the cases in which they did trust the sincerity of the conversion. ${ }^{69}$ The lingering suspicion was particularly clear in the case of mass forced conversions. ${ }^{70}$ In the period which concerns us here, a pertinent case is the ninth-century Christian Qūmis ibn Antunyān. Like the Jew Ḥasday ibn Shaprūt, Qūmis was a highly-Arabicised dhimmī, who reached a high position at court in Cordoba. Unlike Hasday, but perhaps like his descendants,

67 Wasserstein, 'What's in a Name', p. 147.

68 This ambivalence or uncertainty goes, I believe, beyond the simple fact of recalling the convert's origins as an abuse. For such cases, see Wasserstein, 'What's in a name', p. 146 and note 27. Observations of similar state of uncertainty in other historical contexts were also dubbed by historians 'untidiness' (Thomas Sizgorich) or 'messiness' (Elizabeth Key Fowden); see Papaconstantinou, 'Introduction', p. 21. A similar 'untidiness' is noted by Fierro, 'Cuatro preguntas', pp. 237-239 and pp. 245-246.

69 Thus, for example, Ibn Abī Ușaybi 'a, 'Uyūn al-Anbā', p. 653, who says about Ibn al-Mutrān: 'He converted to Islām, and he became a good Muslim (aslama, wa-hasuna islāmuhu)'. This, and other cases, are listed by Fiey, 'Coversions à l'Islam', p. 21 and note 36. See also Yohanan Friedmann, 'Conversion, Apostasy and Excommunication In the Islamic Tradition', in Yohanan Friedmann (ed.), Religious Movements and Transformations in Judaism, Christianity and Islam (Jerusalem: The Israel Academy of Sciences and Humanities, 2016, pp. 109-177, at pp. 110-113.

70 See, for example, 'Abd al-Wāhid al-Marrākushī, al-Mu jīb fi Talkhiṣ Akhbār al-Maghrib, ed. R. Dozy, Leiden: Brill, 1881, p. 435; Stroumsa, Maimonides in his World, pp. 57-58; Fierro, 'Conversion, ancestry and universal religion', pp. 160-161, 165. Historians like Ibn Abī Ușaybi 'a and Ibn alQifți do not present the forced converts as doubtful cases, but rather as clear cases of dissimulating conversion to Islam only as long as the religious persecution lasts; see, for example, Ibn al-Qifțī, Ta'rïh al-Hukamä', ed. I. Lippert, Leipzig, 1903, p. 392. See also Fiey, 'Coversions à l'Islam', pp. 21-23. Further on the phenomenon of such mistrust, see Papaconstantinou, 'Introduction', p. 22; Zorgati, Pluralism, p. 149. 
'when pressed by circumstances, he finalized the process of conversion by a formal profession of Islam'. ${ }^{71}$ But typically, when his rivals question his political loyalty, his conversion is either forgotten, or its sincerity is challenged. For Jessica Coope, the characterization of Ibn Antunyān as a Christian even after his conversion suggests that for some of his Muslim rivals, a convert was not a real Muslim, or at least not real enough to be in a position of power. ${ }^{72}$ Thus, although, as mentioned above, the Jewish and Christian communities of al-Andalus, qua communities, reacted very differently to the pressure to convert, we find that Jewish and Christian individuals who belonged to the same social class confronted the same socio-cultural challenges. In the highly acculturated upper echelons of Andalusian society both Christians and Jews could find themselves in this liminal religious position.

But by describing the religious state of the Banū Hasday as 'liminal' I do not mean to indicate only that the sincerity of their conversion was held in doubt, but also that there appears to have been some genuine, puzzling confusion regarding whether or not they converted at all. I agree with Arietta Papaconstantinou, that 'if we want to observe and understand the phenomenon we call 'conversion'... we need to pay attention to where contemporaries situated the ... break and how they construed it'. ${ }^{73}$ It seems, however, that the contemporaries of the Banū Hasday, as recorded by Muslim historians or reflected in their writings, did not quite know where to situate the break and how to construe it.

Furthermore, the liminality does not refer only to the way others perceived these converts, but also to the position of the converts themselves (or, at least, what our sources tell us regarding this position). At times, the liminality designates a grey area of near conversion, or of recent but indecisive conversion. In some cases, this grey area could be seen in the 'shifting conversions' of one individual, that is to say: conversion, retraction, and (sometimes) then re-

71 Jessica A. Coope, The Martyrs of Córdoba: Community and Family Conflict in an Age of Mass Conversion, Lincoln-London: University of Nebraska Press, 1995, p. 88. On Qūmis (or Qaumis) ibn Antunyān, kātib to Muhammad I, see E. Lévi-Provençal, Histoire de l'Espagne musulmane, Paris: Maisonneuve - Leiden: Brill, 1950, vol. I, pp. 289-291; Kenneth Baxter Wolf, Christian Martyrs in Muslim Spain, Cambridge: Cambridge University Press, 1988, pp. 14, 87; Ibn al-Qūtiyya, Ta'rïkh iftitāh al-andalus: Historia de la conquista de España de Abenalcotía el Cordobés, ed. and trans. J. Ribera, La Coruña: Órbigo, 2014, pp. 67-69; al-Khushanī, Historia de los Jueces de Córdoba por Aljoxaní, ed. and trans. Julián Ribera, Madrid: Ibérica, 1914, pp. 159-164; Fierro, 'Cuatro preguntas', pp. 245-246; Maribel Fierro, 'Abd al-Rahmān III: The First Cordoban Caliph, Oxford: Oneworld, 2005, p. 23.

72 Coope, The Martyrs of Córdoba, p. 88. This, too, is not unique to the reception of converts in Islam. Christians, for example, reacted with similar antagonism to Muslim converts in the courts of the Norman Kings of Sicily; see Kedar, Crusade and Mission, p. 54

73 Papaconstantinou, Conversion in Late Antiquity: Christianity, Islam and Beyond, p. 11. 
conversion, as was not unusual in the early stages of Islamic rule. ${ }^{74}$ Such liminal, complex religious identity is attested in other moments in the history of the Iberian peninsula, especially in the case of forced conversions. Thus, after the expulsion of Jews by the Catholic kings, new Christians remaining on Iberian soil continued to have family and business contacts with Jews who had settled elsewhere in the Mediterranean basin and had returned openly to practice Judaism. The latter would be known as 'new Jews' when in Italy or in North Africa, but they would resume a Christian identity when trading in Spain or Portugal. Such a double religious identity does not seem to have remained a secret to the Christian authorities, and was also known to the Jewish community leaders. As a result, both Christians and Jews often regarded the "new Christians/new Jews' with suspicion and mistrust. ${ }^{75}$

In the case of the Banū Hasday, however, we have no evidence of shifting conversions. We do have evidence for some mistrust regarding the conversion of Abü'l-Faḍl, if he did convert. But mostly, what we have are reports of a seemingly rolling conversion, repeated over several generations.

Let me conclude on an inconclusive note, as I believe befits our findings. It seems safe to say that Abū Ja far Yūsuf bn. Ahmad bn. Hasday died in Egypt as a Muslim. Beyond that, I admit that I find it impossible at this point to say which member of the Ibn Hasday family converted and when. But the accumulated information regarding their religion and the way their religious identity is discussed, both in the sources and in modern studies, draws the profile of religious liminality.

Between cultural assimilation and religious and social pressures, the choices available to members of the minorities covered a broad spectrum, allowing for more nuances and ambivalence than 'conversion' normally suggests. We tend to regard individual conversion as an act of breaking with one's past and choosing another 'life'. Whether described as a cutting, sometimes brutal act, or as a lengthy process of coming to terms with the decision to change one's religion, we expect the process to be over within the lifespan of the individual. The case of the Banū Hasday seems to indicate that individual cases of conversion could also be a protracted gradual move in the life of a whole family. In the context of

74 See Simonsohn, 'Conversion, Apostasy and Penance', pp. 197-218. The shifting conversions are probably a good example of what Arthur Darby Nock had suggested calling 'adhesion' rather than conversion; see A. D. Nock, Conversion: The Old and New in Religion from Alexander the Great to Augustine of Hippo, Oxford: Oxford University Press, 1933; reprinted Baltimore: Johns Hopkins University Press, 1998, p. 12.

75 See Francesca Trivellato, The Familiarity of Strangers: The Sephardic Diaspora, Livorno, and Cross Cultural Trade in the Early Modern Period, New Haven: Yale University Press, 2009, pp. 47, 53, 6869. The attitude of mistrust applied to both conversion and repentance; see Simonsohn, 'Conversion, Apostasy and Penance', pp. 208-221. 
dignitaries in a highly acculturated community, as the Jewish community of alAndalus was, the process that starts with distancing oneself from the old religion and ends with complete integration into the new one, could well span several generations.

\section{List of Abbreviations}

Ashtor, The Jews of Moslem Spain = Eliyahu Ashtor, $\underline{\text { The Jews of Moslem Spain }}$ (Philadelphia: The Jewish Publication Society of America, 1984).

Beinart, Los Judíos en España = Haim Beinart, Los Judíos en España (Madrid: Mapfre, 1992).

Ben-Sasson and Ettinger, Jewish Society = H.H. Ben-Sasson and S. Ettinger (eds.), Jewish Society Through the Ages (New York: Schocken, 1969).

Biblioteca de al-Andalus = Biblioteca de al-Andalus, ed. Jorge Lirola Delgado and José Miguel Puerta Vílches (Almería: Fundación Ibn Tufayl de Estudios Árabes, 2004).

Bulliet, Conversion to Islam = Richard W. Bulliet, Conversion to Islam in the Medieval Period: An Essay in Quantitative History (Cambridge, Mass.: Harvard University Press, 1979).

Burns, Muslims, Christians, and Jews = Robert I. Burns, Muslims, Christians, and Jews in the crusader kingdom of Valencia: Societies in symbiosis (Cambridge: Cambridge University Press, 1984).

Coope, The Martyrs of Córdoba = Jessica A. Coope, The Martyrs of Córdoba: Community and Family Conflict in an Age of Mass Conversion (Lincoln-London: University of Nebraska Press, 1995).

Fierro, 'Cuatro preguntas' $=$ Maribel Fierro, 'Cuatro preguntas en torno a Ibn Ḥafșūn’, Al-Qanțara 16 (1995), pp. 221-257.

Fierro, 'Conversion, ancestry and universal religion' = Maribel Fierro, 'Conversion, ancestry and universal religion: the case of the Almohads in the Islamic West (sixth/twelfth-seventh/thirteenth centuries)', Journal of Medieval Iberian Studies 2/2 (2010), pp. 155-173.

Fiey, 'Conversions à l'Islam' = Jean Maurice Fiey, 'Conversions à l'Islam de Juifs et de Chrétiens sous les Abbassides d'après les sources arabes et syriaques', in Johannes Irmscher (ed.), Rapports entre juifs, chrétiens et musulmans: Eine Sammlung von Forschungsbeiträgen (Amsterdam: A.M. Hakkert, 1995), pp. 13-28. 
García-Arenal, 'Rapports entre les groupes' = Mercedes García-Arenal, 'Rapports entre les groupes dans la péninsule Ibérique: La conversion de juifs à l'islam (XII $-\mathrm{XIII}{ }^{\mathrm{e}}$ siècles)', Minorités religieuses dans l'Espagne médiévale. Revue du Monde Musulman et de la Méditerranée 63-4 (1992), pp. 91-102.

Gervers and Bikhazi, Conversion and Continuity = Michael Gervers and Ramzi Jibran Bikhazi (eds.), Conversion and Continuity: Indigenous Christian Communities in Islamic Lands, Eighth to Eighteenth Centuries (Toronto: Pontifical Institute of Mediaeval Studies, 1990).

Goitein, A Mediterranean Society = S.D. Goitein, A Mediterranean Society; the Jewish Communities of the Arab World as Portrayed in the Documents of the Cairo Geniza (Berkeley: University of California Press, 1967-93). 6 vols.

Hirschberg, A History of the Jews in North Africa = H. Z. Hirschberg, A History of the Jews in North Africa (Leiden: Brill, 1974), 2 vols.

Ibn Abī Ușaybi 'a, 'Uyūn al-Anbā' = Ibn Abī Ușaybi 'a, 'Uyūn al-Anbā' fì Ṭabaqāt alAțibbā', ed. Nizār Riḍā (Beirut: Maktabat al-ḥayāt, n.d.)

Ibn Bassām, Dhakhìra = Abū al-Ḥasan 'Alī Ibn Bassām al-Santarīnī, Al-Dhakhìra fì Mahāsin Ahl al-Jazìra. ed. Sālim Mușțafā al-Badrī (Beirut: Dār al-kutub al'ilmiyya, 1998). 4 vols.

Ibn Dihya, Mutrib = Ibn Dihya, Al-Mutrib min Ash 'ār ahl al-Maghrib, edited by Ibrāhīm al Abyārī, Ḥamīd 'Abd al-Majīd and Aḥmad A. Badawī (Cairo: alMaṭba'a al-āmīìyya, 1954) (= edited by Mușțafā 'Iwaḍ al-Karīm [Khartum: Mațba at Miṣr, 1957]).

Ibn Ezra, Muhādara = Moshe ben Ya'aqov Ibn 'Ezra, Kitāb al-Muhādara wa'lMudākara. Ed. Montserrat Abumalham Mas (Madrid: Consejo Superior de Investigaciones Cientificas, 1985), 2 vols.

Ibn Șā'id, Ṭabaqāt al-Umam = Ṣā'id Ibn Șā'id al-Andalusī, Ṭabaqāt al-Umam, ed. Ḥ. Bū 'Alwān (Beirut: Dār al-țalī'a, 1975); French translation by Régis Blachère, Kitâb Tabakâat al-Umam (Livre des Catégories des Nations) (Paris: Larose, 1935); English translation by Sema' an I. Salem and Alok Kumar, Science in the Medieval World: 'Book of the Categories of Nations' by Șā id al-Andalusī (Austin: University of Texas Press, 1996).

Kedar, Crusade and Mission = Benjamin Z. Kedar, Crusade and Mission: European Approaches toward the Muslims (Princeton: Princeton University Press, 1984).

López y López, 'Ibn Hasdāy, Abū l-Faḍl' = Á. C. López y López, 'Ibn Hasdāy, Abū lFaḍl', Biblioteca de al-Andalus, ed. Jorge Lirola Delgado and José Miguel Puerta 
Vílches (Almería: Fundación Ibn Tufayl de Estudios Árabes, 2004), vol. III, pp. 303-309.

López y López, 'Ibn Ḥasdāy, Abū Ŷa'far' = Á. C. López y López, 'Ibn Ḥasdāy, Abū Ŷa 'far', Biblioteca de al-Andalus, ed. Jorge Lirola Delgado and José Miguel Puerta Vílches (Almería: Fundación Ibn Tufayl de Estudios Árabes, 2004), vol. III, pp. 309-310.

Al-Maqqarī, Nafh al-țīb = Ahmad b. Muhammad al-Maqqarī, Nafh al-țïb min ghuṣn al-andalus al-rațīb. Ed. Iḥsān 'Abbās (Beirut: Dār Șādir, 1968), 8 vols.

Novikoff, 'Between Tolerance and Intolerance' = Alex Novikoff, 'Between Tolerance and Intolerance in Medieval Spain: An Historiographic Enigma', Medieval Encounters 11 (2005), pp. 7-36.

Papaconstantinou, 'Between Umma and Dhimma' = Arietta Papaconstantinou, 'Between Umma and Dhimma: The Christians of the Middle East under the Umayyads', Annales Islamologiques 42 (2008), pp.127-156.

Papaconstantinou, 'Introduction' = Arietta Papaconstantinou, 'Introduction', in A. Papaconstantinou, Neil McLynn and D. Schwartz (eds.), Conversion in Late Antique Christianity, Islam, and beyond. Papers from the Andrew W. Mellon Foundation Sawyer Seminar. University of Oxford 2009-2010 (Farnham: Ashgate, 2015), pp. xv-xxxvii.

Papaconstantinou et al., Conversion = Arietta Papaconstantinou, Neil McLynn and D. Schwartz (eds.), Conversion in Late Antique Christianity, Islam, and beyond. Papers from the Andrew W. Mellon Foundation Sawyer Seminar. University of Oxford 2009-2010 (Farnham: Ashgate, 2015).

Penelas, 'Some remarks on Coversion' = Mayte Penelas, 'Some remarks on Coversion to Islam in al-Andlaus', al-Qanțara 23/1 (2002), pp. 193-200.

Perès, Esplendor = Henri Perès, Esplendor de al-Andalus. La poesía andaluza en árabe clásico en el siglo XI. Sus aspectos generales, sus principlaes temas y su valor documental. Translated by Mercedes García-Arenal (Madrid: Hipérion, 1983).

Pérès, La poésie andalouse $=$ Henri Pérès, La poésie andalouse en arabe classique au XI siècle. Ses aspects généraux et sa valeur documentaire (Paris: AdrienMaisonneuve, 1937).

Rubin and Wasserstein, Dhimmis and Others = Uri Rubin and David J. Wasserstein (eds.), Dhimmis and Others: Jews and Christians and the World of Classical Islam (Israel Oriental Studies 17 [Winona Lake, Indiana, 1997]). 
Sadeghi et al., Islamic Cultures = Benham Sadeghi, Asad Q. Ahmed, Adam Silverstein, and Robert Hoyland (eds.), Islamic Cultures, Islamic Contexts: Essays in Honor of Professor Patricia Crone (Leiden: Brill, 2015).

Sáenz-Badillos, Literatura Hebrea = Ángel Sáenz-Badillos, Literatura Hebrea en la España Medieval (Madrid: Fundacion Amigos de Sefarad, 1991).

Simonsohn, 'Conversion, Apostasy and Penance' = Uriel Simonsohn, 'Conversion, Apostasy and Penance: The Shifting Identities of Muslim Converts In the Early Islamic Period', in Arietta Papaconstantinou, Neil McLynn and D. Schwartz (eds.), Conversion in Late Antique Christianity, Islam, and beyond. Papers from the Andrew W. Mellon Foundation Sawyer Seminar. University of Oxford 2009-2010 (Farnham: Ashgate, 2015), pp. 197-218.

Stroumsa, Maimonides in his World = S. Stroumsa, Maimonides in his World: Portrait of a Mediterranean Thinker (Princeton: Princeton University Press, 2009).

Szpiech, Conversion and Narrative = Ryan Szpiech, Conversion and Narrative: Reading and Religious Authority in Medieval Polemics (Philadelphia: University of Pennsylvania Press, 2013).

Tolan, Saracens = John Tolan, Saracens: Islam in the Medieval European Imagination (New York: Columbia University Press, 2002).

Wasserstein, 'Conversion and the Ahl al-Dhimma' = David J. Wasserstein, 'Conversion and the Ahl al-Dhimma,' in Robert Irwin (ed.), The New Cambridge History of Islam, Volume 4: Islamic Cultures and Societies to the End of the Eighteenth Century (Cambridge: Cambridge University Press, 2010), pp. 184-208.

Wasserstein, The Rise and Fall of the Party-Kings = David J. Wasserstein, The Rise and Fall of the Party-Kings: Politics and Society in Islamic Spain 1002-1086 (Princeton: Princeton University Press, 1985).

Wasserstein, 'What's in a Name' = David J. Wasserstein, 'What's in a Name? 'Abd Allāh b. Ishāq b. al-Shanā'a al-Muslimānī al-Isrāà îlī and Conversion to Islam in Medieval Cordoba', in Arnold E. Franklin, Roxani Eleni Margariti, Marina Rustow, and Uriel Simonsohn (eds.), Jews, Christians and Muslims in Medieval and Early Modern Times: A Festschrift in Honor of Mark R. Cohen (Leiden: Brill, 2014), pp. 139-154.

Wasserstein, 'Where have all the converts gone?' = David Wasserstein, 'Where have all the converts gone? Difficulties in the study of conversion in alAndalus,' Al-Qanțara 33/2 (2012), pp. 325-342. 
Zorgati, Pluralism = Ragnhild Johnsrud Zorgati, Pluralism in the Middle Ages: Hybrid Identities, Conversion and Mixed Marriages in Medieval Iberia (New York: Routledge, 2012). 